\title{
A Descriptive Study to Assess the Nutritional Status of School Going Children in A Selected School of Delhi
}

\author{
Seema Rani', Neha John² \\ ${ }^{1}$ Associate Professor, ${ }^{2}$ Assistant Professor, Rufaida College of Nursing, Jamia Hamdard, Delhi, India. \\ DOI: https://doi.org/10.24321/2349.2880.202006
}

\section{I $\quad \mathbf{N} \quad \mathbf{F} \quad \mathbf{O}$}

\section{Corresponding Author:}

Seema Rani, Rufaida College of Nursing, Jamia Hamdard, Delhi, India.

E-mail Id:

seema9rani@yahoo.co.in

Orcid Id:

https://orcid.org/0000-0002-3133-448X

How to cite this article:

Rani S, John N. A Descriptive Study to Assess the Nutritional Status of School Going Children in A Selected School of Delhi. Ind J Youth Adol Health 2020; 7(2): 1-4.

Date of Submission: 2020-08-12

Date of Acceptance: 2020-11-02

\section{$\begin{array}{llllllll}\mathbf{A} & \mathbf{B} & \mathbf{S} & \mathbf{T} & \mathbf{R} & \mathbf{A} & \mathbf{C} & \mathbf{T}\end{array}$}

Introduction: Among the leading health problems in India is malnutrition. Malnutrition results in weak immune system and growth and cognitive delay. A descriptive study was conducted to assess the nutritional status of school going children in the age group of $6-13$ years in a selected school of Delhi.

Methodology: A total of 211 children were selected through purposive sampling technique. Structured questionnaire and a record sheet were used to collect the data. Height, weight and Blood Pressure of children were measured by using inch-tape, weighing scale, sphygmomanometer respectively. Descriptive and inferential statistics were employed to interpret the data.

Result: Out of 211 school going children, 144 (66.2\%) were in the age group 6 to 9 years and $67(31.8 \%)$ were in the $10-13$ years age group. In the age group of 6 to 9 years, 140 were underweight and 1 was overweight and rest 3 had normal weight as per Basal Metabolic Index. In 10 to 13 years age group, 60 were underweight and 7 had normal weight. As per Waterlows's classification, all 211 children had normal weight for age. As per Gomez classification of children, in 6 -9 years age group, 52 and in 10-13 years age group 20 had normal nutritional status respectively whereas rest of the children fell in degree I and II malnutrition.

Conclusion: Children and their parents need to be made aware about healthy nutritional practices.

Keywords: School Going Children, Malnutrition, Nutritional Status

\section{Introduction}

NFHS 3 report provides clear evidence of poor state of nutrition among under five children in India. They suffer from some of the highest levels of stunting, underweight and wasting observed in any country in the world. Though,
NFHS 3 has not reported on nutritional status of school age children exclusively. Young children in India fall prey to dual burden of malnutrition i.e. abnormal thinness and overweight or obesity. Inadequate feeding practices of children make it difficult to achieve the needed improvements in children's nutritional status. ${ }^{1}$ 
There are about 900 million people suffering from under nourishment globally. $98 \%$ of this burden is born by the developing countries. Prevalence of undernourishment in the developing countries is 16 percent. Two third of the developing countries' undernourished people live in just seven countries: Bangladesh, China, Democratic Republic of Congo, Ethiopia , India , Indonesia and Pakistan, more than $40 \%$ live in India and China alone. ${ }^{2}$

A study was conducted among school children from various primary and middle level educational facilities from a rural health block. Height and weight were measured following standard procedures. The overall prevalence of under nutrition was $19.2 \%$. The prevalence of underweight was lowest in 5 years old females $(0.0 \%)$ and highest in 6 years males (21.5\%). For Stunting 7 year males recorded the lowest $(0.0 \%)$ and 12 year males the highest $(28.5 \%)$ prevalence. The highest and lowest prevalence of wasting was recorded in 6 year old females (2.56\%) and 9 year old males (24.6\%) respectively. Prevalence of thinness was lowest in 13 year old females (14.2\%) and highest in 13 year old males (47.1\%). The study concludes that the nutritional status of school children are comparatively better even though a large number of children still fall below the cut off for various nutritional indicators. ${ }^{3}$

There is growing awareness about child health across the globe. Children are viewed as the assets of the nation as they determine the future of any country. An important adult health indicator is determined by their nutritional status in childhood. World Health Organization reports suggest that more than half of primary school children are suffering from nutritional deprivation. In developing countries like India approximately $20.8 \%$ of children studying in primary school are affected with protein energy malnutrition. ${ }^{4}$

Malnutrition is an iceberg wherein large proportion of children, pregnant women and toddlers are submerged in water and are invisible. Susceptibility to infection and severity of illness are significantly more in malnourished children. Till the time children are at home with parents, their nutrition is taken care in a better supervised manner and frequent meals are provided to them. As they start their regular schooling at an age of six years, they remain away from home and parents hence their food may not meet the nutritional requirements. Therefore the present study was undertaken to assess the nutrition status of school going children in the age group of 6-13 years i.e. children studying from class one to eight.

\section{Methodology}

The research approach adopted for the study was quantitative approach and the research design was descriptive survey design to accomplish the objectives of the present study. The setting for the study was a private school, in a resettlement colony of South Delhi. Formal approval was taken from the administrative authorities of the school. During the ParentTeacher Meeting, verbal consent was taken from the parents of the children and they were informed about the purpose and nature of the study. The study subjects comprised of school going children in the age group of 6-13 years. A total of 211 children were selected for the study through purposive sampling technique and only those children were included who were present in the school during the study period. Study was carried out for a period of two weeks and the data was collected in the Medical Room of the school. The tool used for the study was structured questionnaire was used to collect the background data and a observational record sheet to record data pertaining to height, weight and blood pressure of children. These parameters were measured by using inch tape, weighing scale, sphygmomanometer respectively. Data collected was entered in an excel sheet and analysis was done using descriptive and inferential statistics. All the school children and teachers were imparted health education regarding nutritious diet to improve the nutritional status of children, though effectiveness of the health education was not assessed as a part of the study. During Parent- Teacher meeting parents were also given the same health education. Health education included display and explanation of posters on healthy nutrition, dietary requirement, cookery rules, etc. along with distribution of healthy snacks to the children, teachers and parents. Descriptive and inferential statistics were employed to interpret the data.

\section{Result}

\section{Table I.Frequency and Percentage of Children as per their Demographic Variables}

$n=211$

\begin{tabular}{|c|c|c|c|}
\hline S. No. & Variable & Frequency & Percentage \\
\hline 1. & Age group in years & & \\
\hline & 6 to 9 & 144 & 68.2 \\
\hline & 10 to 13 & 67 & 31.8 \\
\hline 2. & Gender & & \\
\hline & Female & 78 & 36.9 \\
\hline & Male & 133 & 63.1 \\
\hline 3. & Religion & & \\
\hline & Hindu & 147 & 69.7 \\
\hline & Muslim & 64 & 30.3 \\
\hline
\end{tabular}

$144(68.2 \%)$ children were in the age group 6 to 9 years and $67(31.8 \%)$ were in the age group 10 to 13 years. 78 (36.9\%) were female whereas $133(63.1 \%)$ were male. Out of total 211, 147 (69.7\%) followed Hindu religion and $64(30.3 \%)$ followed Muslim religion (Table- 1 ). Blood pressure of all 211 children was measured and found to be within normal limits. 
Table 2.Classification of Children as per Basal Metabolic Index

\begin{tabular}{|c|c|c|c|c|}
\hline Age group in years & Frequency & Under weight (BMI<18.5) & Normal (BMI=18.5 to 24.99) & Over weight (BMI>25) \\
\hline 6 to 9 & 144 & 140 & 03 & 01 \\
\hline 10 to 13 & 67 & 59 & 07 & 01 \\
\hline
\end{tabular}

Table 3.Classification of Children for Protein Energy Malnutrition as per Gomez Weight for Age

\begin{tabular}{|c|c|c|c|c|c|c|}
\hline $\begin{array}{c}\text { Age } \\
\text { group in } \\
\text { years }\end{array}$ & Frequency & $\begin{array}{c}\text { Weight for Age } \\
\% 90-110 \\
\text { Normal } \\
\text { Nutritional } \\
\text { Status }\end{array}$ & $\begin{array}{c}\text { Weight for Age } \\
\% \text { 75-89 } \\
\text { I degree, Mild } \\
\text { Malnutrition }\end{array}$ & $\begin{array}{c}\text { Weight for Age } \\
\% \text { 60-74 } \\
\text { II degree, } \\
\text { Moderate } \\
\text { Malnutrition }\end{array}$ & $\begin{array}{c}\text { Weight for Age } \\
\% \text { Under } 60 \\
\text { III degree, } \\
\text { Severe } \\
\text { Malnutrition }\end{array}$ & $\begin{array}{c}\text { Weight for Age } \\
\% \text { Above } 110 \\
\text { Overweight }\end{array}$ \\
\hline 6 to 9 & 144 & 52 & 61 & 3 & 0 & 211 \\
\hline 10 to 13 & 67 & 20 & 27 & 7 & 0 & 13 \\
\hline
\end{tabular}

Weight for age\%= $=\frac{}{\text { Weight of normal child of same age }} \times 100$

Expected Weight in $\mathrm{Kg}=$ Age in years $\mathrm{X} 2+8$

Table 4.Classification of Children for Protein Energy Malnutrition as per Waterlow's Height for Age

\begin{tabular}{|c|c|c|c|c|c|}
\hline $\begin{array}{c}\text { Age group } \\
\text { in years }\end{array}$ & Frequency & $\begin{array}{c}\text { Mean of } \\
\text { Height/ Age }\end{array}$ & $\begin{array}{c}\text { Standard } \\
\text { Deviation }\end{array}$ & $\begin{array}{c}\text { Frequency of children with } \\
\text { > Mean-2SD (Normal) }\end{array}$ & $\begin{array}{c}\text { Frequency of children with } \\
\text { < Mean-2SD (Stunted) }\end{array}$ \\
\hline 6 to 9 & 144 & 16.6 & 2.03 & $144(>12.54)$ & $0(<12.54)$ \\
\hline 10 to 13 & 67 & 12.9 & 0.98 & $67(>10.94)$ & $0(<10.94)$ \\
\hline
\end{tabular}

For 6 to 9 years, Mean-2SD=16.6-2×2.03=12.54

For 10 to 13 years, Mean-2SD=12.9-2x0.98=10.94

Table 5.Classification of Children for Protein Energy Malnutrition as per Waterlow's Weight for Height

\begin{tabular}{|c|c|c|c|c|c|}
\hline $\begin{array}{c}\text { Age group } \\
\text { in years }\end{array}$ & Frequency & $\begin{array}{c}\text { Mean of } \\
\text { Weight/ age }\end{array}$ & $\begin{array}{c}\text { Standard } \\
\text { Deviation }\end{array}$ & $\begin{array}{c}\text { Frequency of children with } \\
\text { > Mean-2SD (Normal) }\end{array}$ & $\begin{array}{c}\text { Frequency of children with } \\
<\text { Mean-2SD (Stunted) }\end{array}$ \\
\hline 6 to 9 & 144 & .17 & 0.03 & $144(>11)$ & $0(<.11)$ \\
\hline 10 to 13 & 67 & .20 & 0.04 & $67(>.12)$ & $0(<.12)$ \\
\hline
\end{tabular}

For 6 to 9 years, Mean-2SD $=.17-2 \times .03=.11$

For 10 to 13 years, Mean-2SD $=.20-2 \times .04=.12$

It is evident from Table 2, that out of total 144 children in the age group of 6 to 9 years, 140 were underweight, 1 was overweight and only 3 fell in the category of normal weight as per the basal metabolic index. Data in Table 3 reveals that as per Gomez classification children were classified to identify their nutritional status. Results showed that out of 144 in the age group of 6 to 9 years, only 52 had normal weight for their age, 61 suffered from I degree malnutrition, 3 from II degree malnutrition whereas none had severe malnutrition. 28 in this age group were found to be overweight. It is evident from Tables 4 and 5 that as per Waterlow's classification, out of total 211 children, no one had stunted growth as per their age and height in both age groups.

\section{Discussion}

A cross-sectional study, which aimed to explore nutritional status in school-age slum children, showed that the mean height and weight of boys and girls in the study group was lower than the CDC 2000 (Centre for Disease Control) standards in all age groups. The prevalence of stunting and underweight was highest in age group 11 to 13 years whereas prevalence of wasting was highest in age group 5 to 7 years. The study concluded that the school-age slum children had a poor nutritional status and interventions such as skills-based nutrition education, fortification of food items, effective infection control, and training of public healthcare workers and delivery of integrated programs should be effectively undertaken to improve their nutritional 
status. ${ }^{5}$ The current study findings are in line with the quoted study as in the current one, out of 67 children in the age group 10-13 years, 59 are underweight and 1 is overweight.

A study was conducted on 150 school children from four different schools of Allahabad district, India. Dietary history, height, weight and Mid Upper Arm Circumference and Haemoglobin level were measured of children. Findings suggest that consumption of all the nutrients by majority of the students was comparatively less than the recommended dietary allowances. Data on anthropometry revealed that out of total children screened, mean height and weight in all the age group was significantly less than the National Centre for Health Statistics standards. It is concluded that poor anthropometric indices, undernutrition and iron deficiency anaemia may be due to lower intake of food and nutrients than recommended. ${ }^{6}$ Present study finding revealed similar findings that is 34 out of 67 children in the age group of 10-13 years fell prey to I or II degree of malnutrition.

The current study showed that only 10 (4.7\%) out of 211 had BMI in normal range rest 201 (95.3\%) had weight disorder. These results are supported by the study conducted to screen the school children for identifying early signs of health problems. The study included 201 students in the age group 5-16 years studying in government middle and secondary school. $89 \%$ subjects had weight disorders i.e. Body Mass Index < 3rd percentile or > 95th percentile. ${ }^{7}$

One of the United Nations millennium development goals is to reduce the maternal and child mortality. Despite the green revolution and technology boom there has not been significant difference in health status of children. In a study conducted to assess the nutritional status of school children in Mangalore city, Karnataka, 5.03 percent were found to be undernourished, $2.3 \%$ overweight and $1 \%$ obese. ${ }^{8}$ These results are in partial agreement with current study findings. As per the current study, around 1\% children were overweight but percentage of underweight children was $94 \%$.

A study was conducted among Lodha tribal children in a village of Paschim Medinipur. Results show that 9.1\%, 9.7\% and $3.6 \%$ children were found to be severely underweight, stunted and wasted respectively. ${ }^{9}$ Contradictory to these results; the present study findings revealed that none of the children was severely malnourished or stunted.

\section{Conclusion}

Fairly a large proportion of school going children are malnourished. School health services can contribute significantly in the development of children by providing them the health care services including counselling on health related issues. Information education and communication campaign for children, teachers and parents may be a cost effective means to promote the health of school going children.

\section{Conflicts of Interest: None \\ References}

1. National Family Health Survey India; 2005-06.

2. The State of Food Insecurity in the World: Addressing Food Insecurity in Protracted Crisis. Food and Agriculture Organisation Report; 2010.

3. A Fazili, Mir AA, Pandit BM, Bhat IA, Rohul J, Shamila H. Nutritional Status of School Age Children (5 -14) Years in a Rural Health Block of North India (Kashmir) using WHO Z - Score System. Online Journal of Health And Allied Sciences 2013; 11(2).

4. Shivaprakash NC, Joseph RB. Nutritional Status of Rural School- Going Children (6-12) Years of Mandya District, Karnataka. International Journal of Scientific Study 2014; 2(2); 39-43.

5. Srivastava A, Mahmood SE, Kumar B, Shrotriya VP, Srivastava PM. Nutritional Status of School Age Children: A Scenario of Urban Slums in India (2012). Archives of Public Health 70(1): 1-27.

6. Handa R, Ahamad F, Kesari KK and Prasad R. Assessment of Nutritional Status of 7 -10 Years School Going Children of Allahabad District: A Review. Middle East Journal of Scientific Research 2008; 3(3): 109-115.

7. Saleem SM, Khan MS, Jan SS, Bashir H, Quansun R, Mohsina M, Nelofer M. Integrated School Health Screening Program in Khan Sahab, District Budgam (J\&K). International Journal of Current Research 2015; 7(12): 24454-24457.

8. Kamath R, Kumar M, Pattan Shetty S, Kamath A. Nutritional Status Assessment of School Children in Mangalore City using Multicentre growth reference study WHO 2007 Z - scores. International Journal of Nutrition, Pharmacology, Neurological Diseases 2012; 2(3): 233-236.

9. Bisai S, Bose K, Ghosh A. Nutritional Status of Lodha Children in a Village of Paschim Medinipur District, West Bengal. Indian Journal of Public Health 2008; 52: 203-206. 